\title{
ANALISA DAN PERANCANGAN APLIKASI SURAT MENYURAT PADA BADAN METEOROLOGI, KLIMATOLOGI DAN GEOFISIKA (BMKG) PALANGKA RAYA BERBASIS WEB
}

\author{
Sulistyowati ${ }^{1}$, Amelia Rohmah ${ }^{2}$, Andreyan Dwianto ${ }^{3}$ \\ Program Studi Teknik Informatika ${ }^{1,2} \& 3$ \\ Sekolah Tinggi Manajemen Informatika dan Komputer (STMIK) Palangkaraya \\ Jalan George Obos Nomor 114, Palangka Raya, Kalimantan Tengah \\ Email : sty.kireina@yahoo.com ${ }^{1}$
}

\begin{abstract}
ABSTRAK
Perkembangan teknologi yang begitu pesat memberikan kemudahan bagi manusia dalam melaksanakan berbagai kegiatannya. Proses perkembangan teknologi akan berjalan terus menerus. Kebutuhan masyarakat akan informasi sekarang merupakan hal yang sangat dibutuhkan dalam kehidupan yang modern. Teknologi dalam bidang informasi sekarang ini sudah dapat dimanfaatkan oleh masyarakat luas dari teknologi yang paling sederhana sampai dengan teknologi yang muktahir. Tujuan yang ingin dicapai dalam penelitian Surat Menyurat ini, antara lain :(1)Menganalisa bagian tata usaha di Kantor Badan Meteorologi, Klimatologi, dan Geofisika Palangkaraya dalam mengolah dan menyusun data-data surat masuk maupun surat keluar; (2) Menghasilkan perancangan untuk pembuatan aplikasi surat menyurat yang nantinya akan mempermudah pekerjaan bagian tata usaha dalam pencarian data-data surat baik itu data surat baru maupun data surat lama. Hasil yang diperoleh dari penelitian ini yaitu berupa analisa dan perancangan untuk pengembangan sistem informasi surat menyurat yang dapat digunakan untuk membantu dalam menyelesaikan pengarsipan dan pencarian surat.
\end{abstract}

Kata Kunci : Teknologi, Analisa, Perancangan, BMKG

\section{PENDAHULUAN}

Kebutuhan masyarakat akan informasi sekarang merupakan hal yang sangat dibutuhkan dalam kehidupan yang modern. Teknologi dalam bidang informasi sekarang ini sudah dapat dimanfaatkan oleh masyarakat luas dari teknologi yang paling sederhana sampai dengan teknologi yang muktahir.

Surat adalah suatu sarana dalam berkomunikasi yang digunakan untuk menyampaikan informasi tertulis oleh suatu pihak kepada pihak lain. Informasi yang disampaikan melalui surat dapat berbentuk pemberitahuan, pernyataan, perintah, permintaan atau laporan. Meskipun teknologi komunikasi berkembang sangat pesat, peranan surat belum dapat digantikan. Surat masih memegang peranan penting sebagai sarana penghubung antara dua pihak atau lebih dalam satu kelompok organisasi baik pemerintah maupun swasta.

$$
\text { Kantor Badan Meteorologi, }
$$

Klimatologi, dan Geofisika (BMKG) Palangkaraya yang kegiatannya tidak terlepas dengan kegiatan surat menyurat sebagai sarana komunikasi dengan pihak internal dan eksternal organisasi/perkantoran/perusahaan, system pengarsipan surat sangat dibutuhkan sebagai kegiatan pendukung bagi lancarnya kegiatan maupun system dalam lembaga itu sendiri.

Sistem pengarsipan yang digunakan di dalam kantor Badan Meteorologi, Klimatologi, dan Geofisika (BMKG) Palangka Raya sendiri saat ini masih dikerjakan secara manual dengan menggunakan buku arsip surat keluarmasuk, yang mana dengan cara seperti itu masih memberikan masalah kepada bagian pengarsipan yang sulit untuk mengolah dan mencari data surat dengan mengecek satu persatu buku arsip surat.

Rumusan masalah yang terdapat peda penelitian ini adalah bagaimana analisis dan merancang sebuah sistem yang dapat membantu administrasi surat menyurat pada kantor BMKG Palangka Raya. Sedangkan tujuannya adalah menghasilkan perancangan untuk pembuatan aplikasi yang nantinya dapat membantu bagian tata usaha di Kantor Badan Meteorologi, Klimatologi, dan Geofisika Palangkaraya dalam mengolah dan menyusun data-data surat masuk maupun surat keluar, dan juga mudah dalam melakukan pencarian atau penelururan surat. 


$$
\begin{array}{r|l}
\text { Jurnal Sains Komputer dan Teknologi Informasi } & \text { Page } \\
\text { e-issn: 2655-7460. Volume i No.2, Mei 2019 } & 27-30
\end{array}
$$

\section{TINJAUAN PUSTAKA}

Abdullah (2014) melakukan perancangan sistem pengarsipan surat menyurat pada PDAM Tirta Mon Pase, pada penelitian tersebut membangun sebuah sistem ayng dapat menelusuri surat yang telah masuk ke PDAM tersebut. Selain itu sistem juga mampu melakukan pengarsipan dan pengolahan data surat sehingga proses pencarian lebih mudah. Dalam penelitian ini dibuat menggunakan program yang digunakan untuk melakukan pengembangan dari perancangan ini tidak disebutkan namun jika dilihat dari UI nya perancangan sistem ini dibangun menggunakan program desktop.

Sementara itu Prawono, dkk (2015) membuat sistem pengelolaan mengenai surat masuk dan surat keluar pada STMIK AUB Surakarta. Pada penelitianya telah membuat sebuah sistem tentang manajemen susrat masuk dan keluar, artinya pada penelitian ini agak sedikit berbeda dengan penelitian sebelumnya, bahwa penelitian ini membahasa mengenai bagiamana create nomor susrat, jadi surat yang keluar maupun masuk telah tersistem dengan baik sehingga lebih memudahkan bagi penggunakanya. Kemudian Rustamin dkk (2016) juga melakukan pembuatan sistem pengarsipan surat masuk dan surat keluar pada kantor sekretaria DPRD Provinsi Sulawesi tenggara dengan menggunakan bahasa pemrograman Delphi. Pada penelitian ini membahsa mengenai bagaimana mengarsipkan surat yang masuk dan mendata surat yang keluar dan ditujukan kepada siap, sehingga jika dibandingakn dengan penelitian sebelumnya penelitian ini lebih sederhana dibandingakan dengan sebelumnya.

Sementara penelitian Sulistyowati, dkk (2018) membuat pengarsipan surat menyurat pada BMKG Provinsi Kalimantan Tengah. Sistem dibangun dengan menggunakan bahasa pemrograman Php dan MySql dan berbasis Web. Hal ini karena diharapkan dapat meningkatkan kinerja karyawan untuk melakukan kinerjanya. Hasil nya adalah sebuah sistem berbasis web yang mampu membantu dalam menangai pengarsipan, pemberian disposisi serta memudahkan karywan atau pegawai bagian umum dalam menelusuri dan mencari suratsurat yang telah masuk ke BMKG.

\section{KAJIAN TEORI}

\section{Analisis}

Analisis adalah aktivitas yang memuat sejumlah kegiatan seperti mengurai, membedakan, memilah sesuatu untuk digolongkan dan dikelompokkan kembali menurut kriteria tertentu kemudian dicari kaitannya dan ditafsirkan maknanya. Dalam pengertian yang lain, analisis adalah sikap atau perhatian terhadap sesuatu (benda, fakta, fenomena) sampai mampu menguraikan menjadi bagian-bagian, serta mengenal kaitan antarbagian tersebut dalam keseluruhan. Analisis dapat juga diartikan sebagai kemampuan memecahkan atau menguraikan suatu materi atau informasi menjadi komponen-komponen yang lebih kecil sehingga lebih mudah dipahami.

\section{Surat Masuk}

Surat masuk adalah semua jenis surat yang diterima dari instansi lain maupun dari perorangan, baik yang diterima melalui pos (kantor pos) maupun yang diterima dari kulir (penerima surat) dengan mempergunakan buku pengiriman (ekspedisi). (Wursanto, 1991: 108).

\section{Surat Keluar}

Surat keluar adalah segala komunikasi tertulis yang diterima oleh suatu badan usaha dari instansi lain atau perorangan (Wursanto, 1991 :144). Dari pendapat para ahli tersebut penulis mengambil kesimpulan bahwa prosedur pengelolaan surat masuk dan surat keluar adalah pekerjaan surat menyurat yang harus dilakukan secara tertata dan berurutan dengan kegiatan yang utama yaitu mengelola, mengatur, dan mengurus surat menyurat agar dapat mempelancar administrasi instansi tersebut.

\section{Arsip}

Arsip merupakan salah satu sumber informasi yang memiliki fungsi penting untuk menunjang proses kegiatan administrasi dan manajemen sebuah institusi. Semua kegiatan yang dilakukan oleh institusi tersebut, baik itu berupa proposal, surat-menyurat maupun dokumen-dokumen lain akan menjadi arsip. Informasi yang terekam tersebut merupakan bukti dan juga

\section{HASIL DAN PEMBAHASAN}

\section{Hasil Analisis}

- Surat masuk diterima oleh pegawai BMKG.

- Surat masuk diserahkan ke bagian tata usaha untuk didata dalam buku arsip surat.

- Surat yang sudah didata, difotocopy untuk kebutuhan kantor dan untuk dokumentasi arsip. 
Sulistyowati, Amelia Rohmah \& Andreyan Dwianto. Analisa dan Perancangan Aplikasi 2019

Surat Menyurat pada Badan Meteorologi, Klimatologi dan Geofisika (Bmkg) Palangka Raya Berbasis Web

- Surat keluar dicetak dan didata dalam buku arsip surat.

- $\quad$ Surat keluar dikirim untuk balasan dari surat masuk.

Berdasarkan hasil analisis maka dibuat proses sistem baru. Berikut adalah detail dari proses sistem baru.

- Surat masuk diterima oleh pegawai BMKG.

- Surat masuk diserahkan kebagian arsiparis untuk didata dalam website arsip BMKG.

- Surat di scan kemudian diinput datanya kedalam website arsip BMKG.

- Untuk surat keluar di scan terlebih dahulu sebelum dikirim. Kemudian diinput datanya kedalam website arsip BMKG.

- $\quad$ Surat keluarpun dikirim ke pihak yang bersangkutan.

\section{Perancangan Sistem}

\section{ER-diagram}

Pada gambar 1 menunjukkan bahwa perancangan sistem ini terdiri dari 4 entitas yang masing-masing memiliki atribut yang akan digunakan untuk pembentukan sebuah tabel relasi.

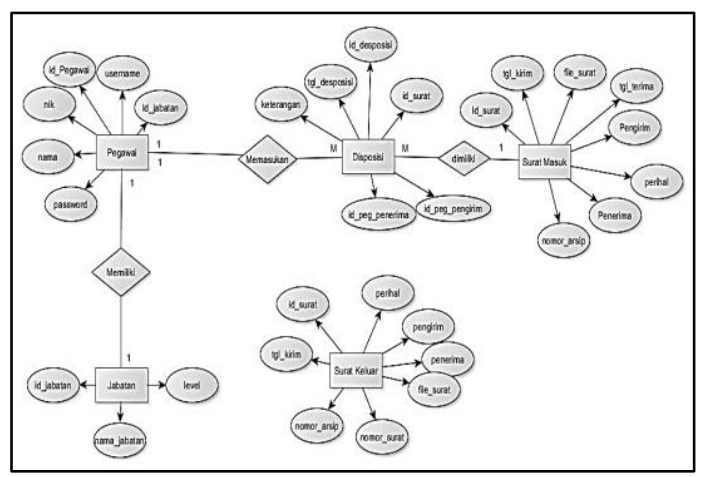

Gambar 1. Entity Relationship

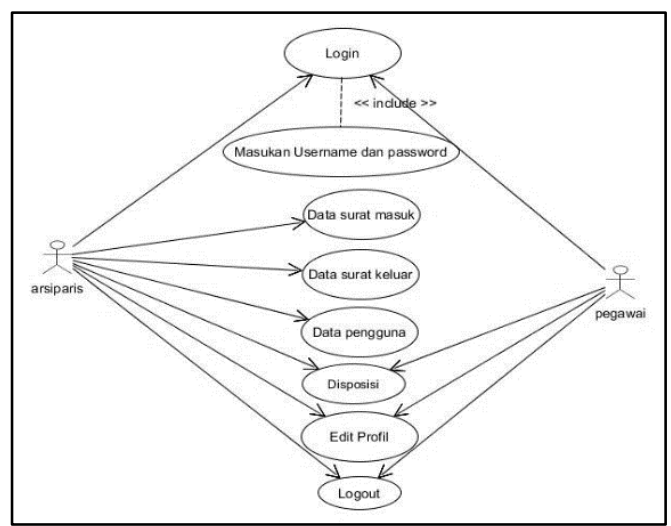

\section{Use case diagram}

\section{Gambar 2. Use Case Diagram}

Use case Diagram pada gambar 2 menunujukkan bahwa terdapat beberapa modul yang dapat diakses oleh pengguna diantaranya adalah memasukkan surat masuk maupun susrat yang telah disposisi. Jadi selain hal tersebut pada gambar juga dijelaskan bahwa user juga bisa melakukan pencarian data pada sistem tersebut.

\section{Relasi antar tabel}

Terdapat 4 tabel yang saling mengambil informasi dari tabel satu dengan yang lainya. Dengan demikian bisa dilihat apa saja yang digunakan pada aplikasi tersebut seperti terlihat pada gambar 3 berikut :

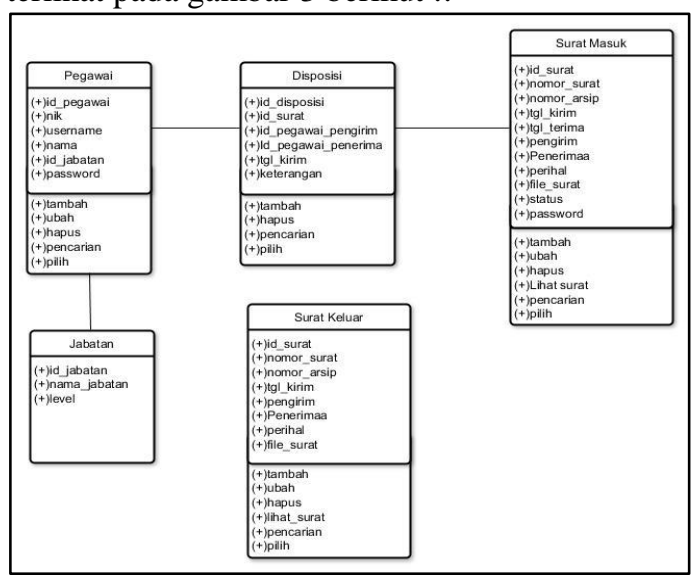

Gambar 3. Relasi Tabel

\section{KESIMPULAN}

Berdasarkan hasil dari analisa dan perancangan untuk pembuatan aplikasi pengarsipan surat menyurat pada Badan Meteorologi, Klimatologi, dan Geofisika (BMKG) Palangkaraya, maka perlu dilanjutkan ke tahap membangun aplikasi tersebut yang nantinya akan dapat memecahkan masalah yang terdapat pada bagian pengarsipan yaitu sudah terkomputerisasinya sistem pengarsipan surat menyurat dan meningkatnya kinerja karyawan khususnya pada bagian arsiparis dalam mengelola pengarsipan surat menyurat.

\section{SARAN}

1. Perlunya pengembangan aplikasi berdasarkan rancangan yang telah dibuat sesuai dengan kebutuhan pengguna (arsiparis).

2. Perlunya server pada kantor administrasi Badan Meteorologi, Klimatologi dan 


$$
\begin{array}{r|l}
\text { Jurnal Sains Komputer dan Teknologi Informasi } & \text { Page } \\
\text { e-issn: 2655 7460. Volume i No.2, Mei 2019 } & 27 \text { - 30 }
\end{array}
$$

Geofisika (BMKG) Palangkaraya agar aplikasi yang dibangun nantinya tidak hanya digunakan untuk satu komputer saja.

\section{DAFTAR PUSTAKA}

Jurnal Ilmiah DASI, Volume 14, No. 4, bulan Desember 2013. Perancangan Online Marketplace Untuk Usaha Kecil Dan Menengah (UKM) Di Kabupaten Purworejo, Wisnu Yoga Sadgotra dan Eric Hadi Saputra: 54-58.

Jurnal Ilmiah, Volume 1, No. 1, bulan Februari 2015. Business To Business(B2B)EMarketplace Sebagai Media Promosi Produk Usaha Kecil Dan Menengah (UKM), Mansur: 1-13.

Jurnal Sains Komputer dan Teknologi Informasi. Vol 1 Issue 1 , bulan November 2018. e-ISSN 2655-7460 Rancang Bangun Aplikasi Pengawasan Dan Pengendalian Komputer Laboratorium Multimedia STMIK Palangkaraya. Sam'ani. 33-38. https://doi.org/10.33084/jsakti.v1i1.548

Jurnal Sistem Informasi, Volume 2, No. 1, bulan April 2010. Upaya Pengembangan Usaha Kecil Dan Menengah (UKM) Dengan Memanfaatkan E-Commerce, Jaidan Jauhari: $159-168$

Jauhari, Jaidan, 2010, Upaya Pengembangan Usaha Kecil Dan Menengah (UKM) Dengan Me Manfaatkan E-Commerce, Jurnal Sistem Informasi Fakultas Ilmu Komputer UNSRI.

Management Journal,, vol. 20, pp. 286-298, 2002. "e-Marketplaces: Crafting A Winning Strategy". European, P. Brunn, M. Jensen dan J. Skovgaard

Jogiyanto, H. M. 2010. Analisis dan Desain. Andi Offset, Yogyakarta. 